Dziubińska Agnieszka, $\mathrm{PhD}$ in Economics, Assistant professor, University of Economics in Katowice, Katowice, Poland ORCID: 0000-0003-4385-1123

Marcin Komańda, $\mathrm{PhD}$ in Economics, Assistant professor, Opole University of Technology, Opole, Poland ORCID: 0000-0003-1695-2949 RESEARCH ID: G-6488-2012

\title{
AN ADAPTIVE PERSPECTIVE TOWARD MULTINATIONAL COMPANY LEARNING ON FOREIGN MARKET. CONSEQUENCES FOR ORGANIZATIONAL ARCHITECTURE
}

Globalization processes can be regarded as one of the most significant trends that have shaped the contemporary social and economic reality. In spite of huge achievements, the discussion revolving around these broad changes may be basically reduced to two opposing approaches. The supporters of the first approach are convinced about the convergence of institutions and market practices under the influence of the actions of countries and companies from the largest, mature markets. Their adversaries point out at the significance of local conditionings and assume that the burden of adaptation lies with the organizations that enter the foreign market. The discourse did not lead to any consensus also in case of the issues related to the organization of MNC that create a particularly convenient ground for pondering these tensions although contemporary economic reality makes them definitely more universal. The above-mentioned issue constituted a direct inspiration to the author's own studies within the framework of which the following research question was posed: what is the relationship between exploration and exploitation learning and adaptation of the international company, and how can they be managed within the scope of organizational configuration? The paper addresses the research questions based on the following structure. First, the issue of adaptation based on single-loop learning (exploitation) and double-loop learning (exploration) were presented. Then the tensions between exploration and exploitation were referred to the issue of organizational configuration. The conclusions resulting from the discussion in both 
fields made it possible to create a conceptual framework that arranges the issues related to the adaptation of MNCs in four domains. Finally, a conclusion is provided that highlights the theoretical and managerial implications of this research, its limitations as well as potential paths for further research.

Keywords MNC, Emerging Markets, Organizational Learning

\section{Агнешка Дзюбінська, Марцін Команда. Перспектива адаптації} мультинаціональної компанії шляхом вивчення іноземного ринку. Наслідки для організаційної архітектури.

Процеси глобалізації можна розглядати як одну з найбільш значущих тенденцій, що сформували сучасну соціальну та економічну реальність. Незважаючи на величезні досягнення, дискусія навколо циих широких змін, в основному може бути зведена до двох протилежних підходів. Прихильники першого підходу впевнені в конвергенції інститутів та ринкової практики під впливом дій країн $і$ компаній з найбільших, зрілих ринків. Їх противники вказують на важливість врахування місцевих умов та припускають, що тягар адаптаиіі лежить на організачіях, що виходять на зовнішній ринок. Дискурс не призвів до консенсусу також $і$ у випадку питань, пов'язаних з організаиією МНК, хоча сучасна економічна реальність робить їх безумовно більш універсальними. Вищезгадане питання стало поштовхом для власних досліджень автора, в рамках яких було поставлено наступне дослідницьке питання: який взаємозв'язок між дослідженням і прикладним навчанням та адаптацією міжнародної компанії та як ними можна керувати в межах сфери організаційної конфігурації. У статті розглядаються питання, виходячи 3 наступної структури. По-перше, було висвітлено питання адаптації, заснованої на однобічному вивченні (прикладному) та двобічному вивченні (розвідиі). Далі у статті відповідність між дослідженням (розвідкою) та прикадним вивченням було віднесено до організачійної конфігураџії. Висновки, отримані в результаті обговорення в обох сферах, дали можливість створити конщептуальну основу, яка б упорядковувала питання, пов'язані з адаптацією МНК у чотирьох областях. Надано висновок, який висвітлює теоретичні та управлінські наслідки цього дослідження, його обмеження, а також потенційні шляхи подальших досліджень.

Ключові слова: МНК, нові ринки, організачійне вивчення.

Relevance of research topic. Globalization processes can be regarded as one of the most significant trends that have shaped the contemporary social and economic reality (Giddens, 1999). Multinational companies (MNCs) which, acting on the wave of business activity integration contributed also to the changes in the conditioned local political, institutional, organizational and cultural systems, are considered to be the main agents in globalization processes (Kostava \& Roth, 2002). In spite of huge 
achievements, the discussion revolving around these broadly outlined changes may be basically reduced to two opposing approaches. The supporters of the first approach are convinced about the convergence of institutions and market practices under the influence of the actions of countries and companies from the largest, mature markets. Their adversaries point out at the significance of local conditionings and assume that the burden of adaptation lies with the organizations that enter the foreign market. The discourse did not lead to any consensus also in case of the issues related to the organization of MNCs. It is not a convenient situation for managers since, on the one hand, contemporary economic reality requires from an organization continuous innovation in the dynamic environment. On the other hand, for stable performance to be achieved enterprises need to maintain continuity and preserve their identity based on the replication of past experiences (Raisch, 2008). Specific conditionings of the activity conducted on the international scale create a particularly convenient ground for pondering these tensions although contemporary economic reality makes them definitely more universal.

Both innovation and flexibility as well as replication and optimization are related to the development of the organization, however, they follow a different logic. Therefore, in the process of adaptation organizations have to solve tensions resulting from equally important but antagonistic development models. Since the pioneering publication by March (1991), exploration and exploitation have been regarded as twin concepts within the scope of studies on the adaptation of the organization. Also, on the ground of International Business, strategic alignment models are built on the basis of opposing choices between global perspective and sensitivity to local conditions (Bartlett \& Ghoshal, 1989, Forsgren, 2008).

In the sphere of theoretical models, it is assumed that for the purposes of maintaining short-term efficiency and long-term innovation it is necessary to have a balance within the scope of exploration and exploitation (March, 1991, Levinthal \& March, 1993). Therefore, at the stage of decision-making processes it is necessary to determine an appropriate relationship between antagonistic models of learning. The difficulty within this scope results, among other things, from the fact that although in the literature the thesis on the relationship between exploration and exploitation with opposing learning models is not controversial, the very characteristics of this relationship is not as clear. As an example, Dougerthy (1996) described a company struggling with multidimensional tensions related to innovation, such as conflicts between the external and the internal, the deterministic and the emergent, freedom and subordination. Sheremata (2000) concentrated on the continuous battle between centripetal and centrifugal forces that drive discoveries thanks to synthesis. Taylor and Greve (2006) pointed out at the span and depth of knowledge as factors that condition product innovation. Greve (2007) studied exploration and exploitation in product innovation as a result of problemist search (identified with exploitation) and slack search (exploration). Anrdiopoulos and Lewis (2009), motivated by the willingness to 
create a more general model, identified strategic paradoxes on three levels: strategic intention (profit-breakthrough), customer orientation (tight-loose), personal motivation (discipline-passion). The efforts within the scope of presenting more practical solutions to tensions between exploration and exploitation in the recent years have been conducted within the framework of organizational ambidexterity (Raisch \& Birkinshaw, 2008, O'Reilly \& Tushman, 2013). Within the conceptual framework the studies have been conducted on various levels of analysis, i.e. organizational (Lubatkin et al., 2006), business unit (Jansen et al., 2012), project (Turner et al., 2015) and individual (Mom et al., 2009). The contexts of various branches have also been taken into consideration (Junni et al., 2013).

The literature within the scope of ways of combining diverse domains of activity within the scope of exploration and exploitation may be divided into two distinct, yet complementary, trends (Raisch et al., 2018). The first trend concentrates on a paradoxical character of the relations between exploration and exploitation. The other one results from the process view of organizational tensions which arise in this way. The very combination of these trends creates a particularly interesting research perspective within the scope of the applied configuration of the organization in the process of adaptation to the changing environment. Specific conditionings of geographically scattered structure of MNCs - adaptive pressure coming from both external and internal environments - make the research problem more visible. The above-mentioned issue constituted a direct inspiration to the author's own studies within the framework of which the following research question was posed: what is the relationship between exploration and exploitation learning and adaptation of the international company, and how can they be managed within the scope of organizational configuration? This paper addresses the research questions based on the following structure. First, the issue of adaptation based on single-loop learning (exploitation) and double-loop learning (exploration) were presented. Then the tensions between exploration and exploitation were referred to the issue of organizational configuration. The conclusions resulting from the discussion in both fields made it possible to create a conceptual framework that arranges the issues related to the adaptation of MNCs in four domains. Finally, a conclusion is provided that highlights the theoretical and managerial implications of this research, its limitations as well as potential paths for further research.

Formulation of the problem. The necessity for continuous revival of the enterprise through simultaneous maintenance of the ability to explore and exploit enforces the verification of traditional strategic models. On the grounds of International Business literature, the concept requires development and identification of ways which would indicate the ways of achieving the assumptions of sustainable development between the competitive types of learning through investments on the foreign markets. One of the research paths within this scope is built on the assumption concerning the development of the organization on the basis of punctuated 
equilibrium. It should be emphasized that it gained greater acceptance in descriptive studies than in prescriptive literature within the scope of strategy and organization. Limited rationality in achieving conflicted targets may serve as an explanation for the sequential allocation of attention in divergent purposes (Cyert \& March, 1992). However, the very perception of the issue of exploration and exploitation development is already problematic.

Gupta et al. (2006) placed the definition issue among their 4 «central questions» related to exploration and exploitation as the research issue. They searched more thoroughly for the decision whether the difference lies in learning models or rather in presence or absence of learning. Some authors claim that exploration and exploitation signify learning and innovations, however, the organization can develop according to the same or new trajectory over time. Baum, Li, Usher (2000) suggest that «exploitation refers to learning gained through local search, experimental redefinition and selection and reuse of routines. Exploration refers to learning gained through the process of coherent differentiation, planned experiment and action» (p. 786, as cited in Gupta et al. 2006). Benner, Tushman (2002) assume that «exploitative innovations encompass the improvement of the existing components and are built on the existing technological trajectory, whereas explorative innovations signify turning to a different technological trajectory» (p. 676, as cited in Gupta et al. 2006). In a similar way He and Wong (2004) define exploitative innovations as «technologically innovative actions aimed at the improvement of the existing product and market domains» (p. 483). The punctuated equilibrium model is especially appropriate for the settings characterized by complexity such as these that paradoxical tensions create (Uotila, 2018).

According to another attitude, exploration stands for all the actions related to learning and innovation, whereas exploitation is reserved for actions based on the past knowledge with no motion on any learning trajectory. Such point of view was assumed, for example, by Rosenkopf and Nerkar while they were studying the influence of searching for local and non-local knowledge on the quality of patents. If the patents were based mainly on local knowledge «it is possible to assume that it is rather a form of exploitation than exploration» (Rosenkopf \& Nerkar, 2001, p. 289). Due to the fact that the studies concerned only R\&D processes and patent actions, the study made use of the term «the most local form of exploration» instead of «exploitation». In the international managerial literature movement, Vermeulen and Barkema identified the decisions about expansion with exploitation since they resulted in «the current use of the existing knowledge base by a company», whereas exploration was defined as «the search for new knowledge» (Vermeulen \& Barkema, 2001, p. 459). In accordance with this assumption, they called all bottom-up investments exploitation, whereas acquisitions were referred to as knowledge exploration. 
Adaptation of the organization considered from the social perspective is an intelligent answer of the actor to various threats and opportunities hidden in the environment. Therefore, it should be assumed that each activity is related to learning. Even if the organization makes an effort to maintain its status quo or grow only through replication, the experience is accumulated which moves the organization to another point on the learning path. As March himself said, «the essence of exploitation is to master and develop the existing competences, technologies and paradigms (...) the essence of exploration is to experiment with new alternatives» (March, 1991, p.85). Not only do these formulations refer to the growth of knowledge itself but they also direct the attention to the ways of change and, in this regard, learning within the framework of exploitation will be in its form closer to the incremental one. The distinction between exploration and exploitation should refer to the ways of learning and the amount of accumulated knowledge, especially if the analysis concerns social systems. In these systems the state of perfect replication is unattainable, the effect of learning will always exist even if it consists in the elimination of deviations against the established patterns on a historically established path (single-loop learning). In the development process, which is expected to bind the organization with the environment, the enterprise should have the skills of moving on the learning path, i.e. learning in new circumstances, learning on the basis of past experiences and, what is equally important, refraining from their extrapolation in the conditions which do not justify that.

Reflective change (on the basis of the learning organization theory) is based on the progressive cognition (understanding) of knowledge and relations between past actions, their efficiency as well as future actions (Huber, 1991). Such learning process is at the same time adaptive and «manipulative» in the way in which organizations defensively adapt to reality and offensively improve the alignment between the organization and environment (Hedberg, 1991). According to the terminology used by Argyris and Schön (1978), organizations have to undertake actions in the single and double loop of learning in order to ensure the continuity of actions, coherence and stability. The first one is of responsive and adaptive nature, it is coupled with the negative feedback with the changes in the environment, directed at the maintenance of the previous equilibrium. This type of learning consists, to a large extent, in the stimulant - response mechanism. The other type of learning corresponds to the characteristics of open systems which assumes reorganization and repositioning of the environment itself or change of the principles of action and system behavior. Argyris calls it a double-loop learning, Hedberg (1981) meta-learning, whereas Beteson (1972) deuter-learning. The core of learning is not to change the system behavior but to change the principles within the system behavior.

The organization uses local knowledge and search in order to develop and improve competences. Simultaneously, the organization has to remain open to 
broadening and discovering new areas of search. Due to the organizational project, which is always to some extent imperfect and incomplete, continuous reflection and monitoring with regard to the changing external and internal environments, which is prone to inertia, is required. Equilibrating of single- and double-loop learning is a significant conclusion for the organizational configuration. Single-loop learning at unchanged values and norms leads to rigidity, continuous questioning of norms, on the other hand, leads to chaos (Weick, 1982). Raising the significance of this issue, Probst and Büchel (1997) distinguished a three-tier learning structure. Apart from adaptive and reconstructive learning as counterparts of single and double loops, they also took into consideration process learning. According to Batesson (1981) it encompasses all phenomena which appear together with the changes in the flow of action and gaining experiences. In other words, it is learning the understanding of adaptive and reconstructive learning. The main task is to improve the ability to learn (Rokita, 2005). Switching - leaping - between single- and double-loop learning is a mechanism which makes adaptation possible. In a long-term perspective it provides an image of sequential leaping between the stable punctuated equilibria.

Tensions between exploration and exploitation constitute a chance for performance improvement but they may also be the reason for organizational failures. At the bottom of them there are traps launched in the form of false circles that consist in the increasing concentration on one of the mechanisms. As it was noticed by March, «adaptive systems that engage in exploration to the exclusion of exploitation are likely to find that they suffer the costs of experimentation without gaining many of its benefits. They exhibit too many undeveloped new ideas and too little distinctive competence. Conversely, systems that engage in exploitation to the exclusion of exploration are likely to find themselves trapped in suboptimal stable equilibria» (March, 1991, p. 71).

Exploration displaces exploitation and vice versa (March, 1991, Tushman \& O'Reilly, 1996). The companies inclined to homogeneity, while experiencing comfort in the course of development of mental models and routines that support one type of innovation, escalate their efforts in the sphere of preferred models while denying the remaining ones (Smith \& Tushman, 2005). The results undermine the effects and they eventually lead to destruction. Leaning too much towards exploitation may lead to a competency trap (Gupta et al. 2006). Asymmetric attachment to exploitation along with the development (time progress) results in the rigidity of key competences, investments in highly-specialized resources, which, in turn, causes the increase in the parameters of short-term effects at the expense of flexibility reduction (Volberda \& Lewin, 2003). Shortly speaking, the use of current competences makes immediate profits possible, but it favors stagnation which makes the company helpless in the face of market and technological changes (Atuahene-Gima, 2005). 
Conversely, Gupta et al. (2006) identify the failure trap triggered by too large inclination for exploration and too superficial analysis of explorative actions. Such companies have a tendency to undertake greater and greater risk while denying previous innovation failures, which favors ignoring of the need for growth within the framework of key competences. Future opportunities are searched for at the expense of current projects (Gibson \& Birkinshaw, 2004). Too high sensitivity to short-term changes, differentiation, local mistakes make the organization too reactive to temporary aberrations and trends and it signifies continuous manipulation in the procedures and routines. In this way the resources are wasted by copying the noise rooted in the environment (Volberda, 2003). «Chaotic organizations» are not able to maintain the significance of their identity and stability over time (Weick, 1979). The revival trap, as a result of chaotic and random exploration leads to conflicts concerning power and authority, unclear scopes of responsibility, inadequate manners of control and lack of clear direction of the shared vision.

Analysis of recent researches and publications. Single and double loop learning makes it possible to explain relatively well the long-term development of the organization. Such view of the issue leaves the decisions within the scope of operational organizational configuration outside the basic area of the analysis. The issue is, however, considered in the studies under the label of ambidextrous organization (AO), within the framework of which simultaneous balance is searched for among contradictory tendencies. The term was used for the first time by Duncan in 1976 in the theory of organization and it was later developed by March (1991). They assumed that management of contradictory tendencies contributes to the improvement of the results of the enterprise (Tushman \& O'Reilly 1996). These suggestions were supposed to serve as an answer to the controversies in the literature concerning such pairs of terms as production efficiency and flexibility (Adler et al., 1999, Gibson \& Birkinshaw, 2004), differentiation and low cost strategy (Porter 1980), and, finally, global integration and sensitivity to local factors (Bartlett \& Ghoshal 1989). In the strategic dimension AOs reconcile strategic paradoxes which enables them to achieve an agreement regarding current operations (coherence of all activity patterns within the framework of the unit) and, at the same time, to effectively adapt to the changing environment (aptitude for quick reconfiguration of the activity) (Gibson \& Birkinshaw, 2004). AO was defined as a form of an organization which includes incoherent internal architecture and culture which constitute a part of organizational units (Adler et al., 1999). The explicit and implicit concepts are derived from the issue of knowledge exploration and exploitation and although they have contradictory requirements within the scope of the organizational project and strategy, balancing actions related to them is the key to adaptation (O'Reilly \& Tushman 2013). With equal dexterity,AOs are able to simultaneously conduct contradictory knowledge 
management processes while exploiting past competences and exploring new domains (Lubatkin et al., 2006).

The studies regarding strategic paradoxes have a relatively long tradition although they focused mainly on the structural organizational project (structural bilateralism) (Andriopoulos \& Lewis, 2009). At that time, dual structures and strategies were recommended in which particular organizational units (or groups within the framework of the units) were responsible for different types of activities. In this way, for example, the units related to management were responsible for alignment, whereas R\&D was responsible for adaptation of actions to the new markets, technologies and trends appearing in the branch (Duncan, 1976). The crowning argument that justified separation from the structure was the fact that each of the group of actions, mental models and routines mentioned are so different from one another that they cannot coexist (Gupta et al., 2006, p. 695). Similar justification was used in case of the suggestion for applying, by the same unit, mechanical structures for the purposes of exercising more routine and organic decisions for the undertaking of nonroutine actions depending on the changes perceived in the environment (Burns \& Stalker, 1961). Separation of activities, especially in the long-term perspective, however, caused burdensome consequences since isolation of the developed ideas and strategies during implementation resulted in the barriers of lack of communication and understanding. The barriers resulting from limited resources the organization can have at its disposal (Gupta et al., 2006) and difficulties in managing units of such differently oriented targets (Schreyögg \& Sydow, 2010) were indicated as limitations to the achievement of ambidexterity on the basis of such organizational configuration.

The concept of «parallel structures» was established as an alternative to dual ones (McDonough \& Leifer, 1983), in which exploitation and exploration were combined within the framework of organizational units, and even particular employees (Andriopoulos \& Lewis, 2009). There were experiments undertaken which consisted in detaching employees from their current work, assigning temporarily tasks in interfunctional teams and creating subgroups within the framework of one organizational unit that were responsible for various functions (Birkinshaw \& Gibson, 2004). The role of leadership was emphasized (Smith et al., 2016). Although, in such way the limitations of negative features of structural separation were to a certain extent neutralized, the structures still remained in the «top-bottom» orientation. The manager of the organizational unit determines the division of time and other resources between competitive actions (Raisch \& Birkinshaw, 2008). Further interest of the researchers began to move from the structural aspect towards the so-called contextual factors, that is social and behavioral factors (Zimmermann et al., 2015). Processes and systems able to ensure reorientation in the way of balancing tensions between contradictory tendencies from trade-off to the acceptance of paradoxes are searched for. Birkinshaw and Gibson (2004) describe the contextual bilateralism as a higher-order approach in 
which supporting social processes (e.g. socialization and cognition practices), culture and interpersonal relations help actors in the whole organization think and act bilaterally (Birkinshaw \& Gibson, 2004). Criticism of the approach concentrated on behaviors (individual and group) concerned lack of organizational tools that would make the realization of the established unrealistic targets possible (Schreyögg \& Sydow, 2010) and the fact that the concepts did not take into consideration a number of factors, e.g. social, institutional ones that shape the behavior of the units (Smith \& Lewis, 2011). The ability to combine contradictory tendencies within the framework of the organization was also regarded as a source of surprising, from the point of view of traditional literature, successes of MNCs from the so-called emerging markets (Luo \& Rui, 2009).

Presenting main material. The potential of exploitation of accumulated, established experiences on a larger, international scale is a classic motive of the internationalization of the enterprise. The analysis of adaptation of MNCs may therefore be conducted with regard to its key competences. The development based on the past experiences consists in the improvement of measurements within the framework of selected directions, known sets of norms and assumptions which guide the organization. The enterprise notices environmental challenges (opportunities, threats) but it does not question the norms and values with which the assessment of reality is conducted. Learning is therefore a process of assessment of efficiency of achieving targets by means of reacting to changes in the environment (Rokita, 2005). Another case is search for revival opportunities in the future. Then, the enterprise should be able to question the previous assumptions, i.e. double-loop learning. Learning on this level is a process that consists in questioning organizational norms and values and builds a new system of reality perception. Another distinguishing feature of MNC is geographically scattered structure of MNC which causes the organizational unit to feel a relatively strong adaptative pressure from the external environment (macro level) and internal environment (micro level) (Madhok \& Liu, 2006). Dimensions of MNC adaptation from the perspective of the organizational unit located on the foreign market were presented in a graphic manner in fig. 1. The assumed perspective of the organizational unit (branch) is justified by the fact that through its agency MNC gains experience on the foreign markets. The shape of the figure in the coordinate system is indicated by the use of resources - knowledge (at a specific ratio) from internal (enterprise) environment or external environments (foreign market) - axis $\mathrm{X}$ and those that favor the improvement within the framework of current or new targets - axis Y, e.g. in undertaking strategic initiatives (projects). The area of the indicated figure results from limited resources that the enterprise has at its disposal, i.e. budget. 


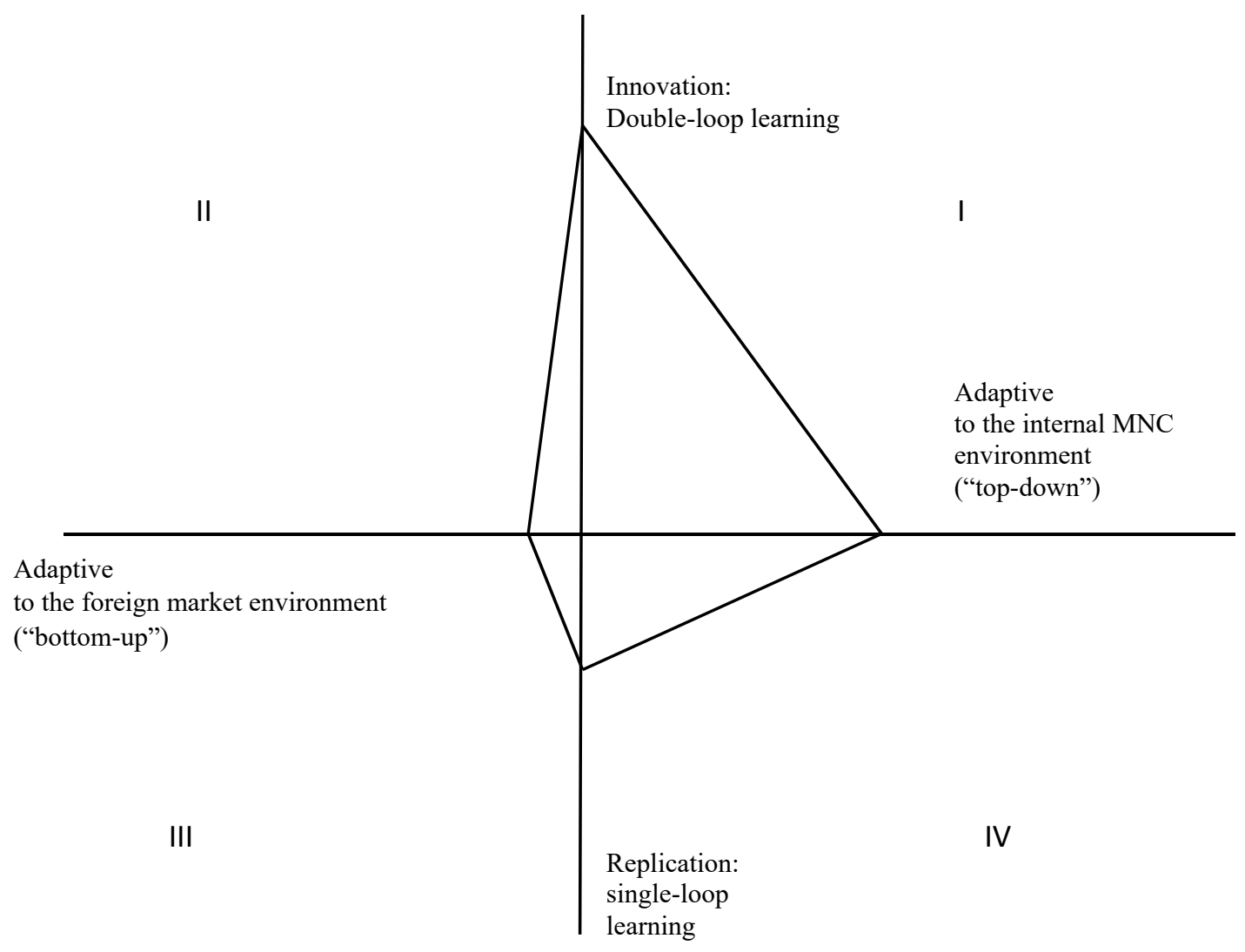

Picture 1. Elements of MNC adaptation - organizational unit level

The asymmetry of the figure made by the indicated level of used resources shows a potential domination of either exploration or exploitation and the level of intentional control

- quarter IV corresponds to traditional strategies envisioned for markets that are the source of cost advantages. Learning aims at the identification and neutralization of all the elements of the local environment which do not comply with the established business model. The example is the behavior of corporations that obtain raw materials in the so-called third-world countries.

- quarter III signifies replication-based learning, i.e. by means of the operational improvement within the framework of the past competences. The example is the behavior of western corporations on the large so-called emerging markets. These are cases of markets that are not regarded as the source of innovation in the field of key competences, but prospective benefits (e.g. market size) dispose to adaptation to the local context to a necessary extent.

- quarter II corresponds to strategic markets and gaining brand new knowledge for the organization in key areas of activity. The actions undertaken in this field will lead to the largest changes in the organization. Investments on the so-called leading markets, i.e. the area of the Silicon Valley for high-tech companies may serve as an example. 
- quarter IV includes actions (projects) that will signify discontinuous change for the branch on the organizational unit level. «Leap to a higher peak» is an expression of the MNC advantage over local market competition (overcoming «liability of foreignness»). The introduction of the technological standard previously absent on a given market, developed on the basis of experience gained on other markets may serve as an example.

At this point it is worth highlighting that although the examples of geographically identified markets were used, it does not have to be a regular pattern. Emerging markets may constitute a source of strategic innovation, whereas mature markets may periodically assume the features of emerging markets. The presented elements of adaptation should therefore be given a dynamic interpretation.

The process view of adaptation, in case of MNCs, points out in a clear manner at the consequences of conducting the analysis at a particular level. The effect of learning (knowledge growth) may be limited at the level of a single element (e.g. single organizational unit), whereas, at the level of a group through the differentiation of contexts in which particular units and interactions between them are located, it will take place in a broader scope. The change at the organizational unit level may be interpreted as discontinuous, groundbreaking - explorative, whereas at the level of the entire organization it may result from exploitation-based incremental development. The concepts of both punctuated equilibrium and time oscillation between a longer period of exploitation interrupted by shorter periods of exploration gained in the literature, in the opinion of some authors, acceptance as coherent ones that correspond to practice. The results may be referred to the strategic MNC models in Bartlett's and Gshoshal's typology (Bartlett \& Gshoshal, 1989), where the position of headquarters with regard to organizational units and strength of interactions between organizational units were taken into consideration.

According to Gupta et al. (2006), if exploration and exploitation are analyzed within the framework of a single domain (e.g. person or subsystem), they are conceptualized as two ends of the continuum, the subsystem behaves according to the punctuated equilibrium model. Applying the system language (Raisch et al., 2018), it is the case in which innovation occurs in architecture at the level of the entire system, and long-term adaptation of architecture at this level requires sequential switching between exploration and exploitation. The conditionings of global and transnational MNC model, which are characterized by a strong position of the headquarters against organizational units and strong interactions between them, correspond to this case. Adaptation gains another expression if the analysis concerns a group of loosely connected domains. Then, exploration and exploitation become an «orthogonal» problem (congruent with the logic of ambidexterity). Referring again to the language of designing systems, exploration may be realized in one system module, whereas exploitation in another one (Gupta et al., 2006). These conditionings correspond to the assumption of a multinational and international MNC model which are characterized 
by a relatively strong position of organizational units and weak interactions. In a more general way, the summing up of the above-mentioned arguments with regard to the configuration of international enterprises may be conducted in the following way. When the analysis concerns a single domain, i.e. branch of the enterprise, the logic of punctuated equilibrium (exploration and exploitation as two ends of the continuum of possible solutions) is a more appropriate adaptation mechanism. The analysis conducted on the level of relatively loosely connected domains - at the level of the entire international enterprise - exploration and exploitation are in an orthogonal relationship and the logic of ambidexterity seems to be a mechanism that suits adaptation better.

Conclusion. Contemporary enterprises experience everlasting and continuously increasing tensions between targets that guarantee economically stable development and these ones which, being a condition for long-term survival, require strategic revival (technological, ecological and cultural). Additionally, MNCs, while crossing country borders, experience new challenges that result from the fact of joining the competition of enterprises coming from markets which until recently were regarded as periphery countries in the world economy, deprived of sources of strategic advantages. These are only examples of tendencies which the image of a complex environment that requires from the organization an equally complex response is composed of. In the light of it, the basic axis of the discourse mentioned in the introduction regarding a progressive development of activities on the global scale should not focus on who should adapt but rather on how adaptation should be conducted, since diversity is the only thing that may destroy diversity (Ashby, 1956). These conditionings cause, on the one hand, the need for review of the past theory. On the other hand, the ability to combine contradictions has never seemed to be so significant.

The conclusions that may be drawn on the basis of observation of the contemporary scene of competition of companies operating on the international scale find their reflection in the literature concerning organizational adaptation. In the process of avoiding threats and taking opportunities organizations learn by deriving from past experiences and gaining new ones. A rich theory corresponds to this fundamental problem in the management. Among the newest propositions there is a concept of oscillation between the states of exploitation and exploration (Thomas et al., 2005), which correspond to convergent and divergent strategic processes (Dooley \& Van de Ven, 2017, Dziubińska, 2015). Convergence consists in the pursuit of dynamic equilibrium (Smith \& Lewis, 2011) and synthesis. Divergence means movement outside the equilibrium, search for new paths of development for the organization. The development of this very attractive strategic perspective is not yet accompanied by a satisfactory increase in the studies within the scope of organizational configuration. The results of the studies of past literature within the scope adaptation and organization presented in this article constitute an attempt to sharpen the noticed research area. The formulated concept is a proposition for a 
stepping stone between the past theoretical work and the new views that appear. In the coordinate system presented in fig. 1, the vertical dimension corresponds to the abovementioned, on the one hand, convergent, classificatory tendencies, i.e. exploitation, and, on the other hand, divergent tendencies, questioning the past order, i.e. exploration. The MNC perspective makes another issue visible, i.e. the relationships between the remaining part of the organization and the significance of the differences in the contexts in which they are located (horizontal dimension). «Top-down» knowledge requires a specific level of generality which may gain (or not) a more polysemous significance in the unique context of the foreign market. Actors competing on the foreign markets make choices, judgements and manifest creativity. In this way they may initiate transformation of themselves as well as transformation of the system which they are a part of. Such transformation is closer to ontologically open and irreversible processes which take place in real historic time rather than to closed and deterministic transformation processes from one obtained state to another one.

The presented view of MNC adaptation reveals problems which were not considered synthetically so far with regard to the strategic types of MNC. Although thinking about international strategies in their contemporary shape has been since the beginning accompanied by the idea of exploitation of the accumulated previous experience, from the point of view of learning, basic differences within this scope should be noticed. Its directions and effects may be shaped by the intention to achieve as accurate replication as possible (quarter IV). Replication in which the past experiences are reinterpreted constitutes a qualitatively different situation (quarter III). It is assumed that the alignment of targets of the entire organization and unit is possible although it requires more time and is of more ambiguous nature. The application of the past solutions in a creative manner in the new conditions entails a potential for incremental improvement. The initiatives which correspond to the convergent processes of the strategy - lower part of the coordinate system in fig. 1 are of a completely different nature. Even if the actions of the unit are limited by the targets formulated on the higher level of management (quarter I), it happens more gradually than in previous cases. These targets may be changed under the influence of actions undertaken on the foreign market. It is a situation in which incremental development may be interrupted by a discontinuous change. Change mechanisms rest in negative and positive feedbacks. Intentional use of their action boils down to the strengthening of positive results and dampening these actions which may cause negative results (Arthur, 2009). If the limitation by «top-down» targets does not occur, it is a situation in which there is the greatest innovation potential (quarter II). It is a situation in which completely new solutions for MNC can be expected, however, this approach also disposes (but does not pre-dispose) to discontinuous changes to the largest extent. The ex-ante estimation of the results of these changes is very difficult to make. Therefore, the same significance should be attached to both innovation and borders that result from the budget of available resources. Although in the situations 
which correspond to convergent strategies and experience exploitation (quarters IV and III) the past theoretical suggestions for the solution within the scope of MNC configuration seem to offer sufficiently good recommendations, divergent conditionings of two remaining situations (quarters I and II) enforce the development of a new approach.

Summing up, the presented view of MNC adaptation to complex conditionings of the contemporary economic reality suggests the necessity to exploit the past knowledge and to explore within the scope of new research paths. Critical awareness of such need is the first step towards intentional management of relations between exploration- and exploitation-based learning and adaptation of MNC. Finally, it should be emphasized that limitations resulting from the abstractive nature of the presented considerations were dictated by the attempts to essentialize and understand the research problem in a holistic manner. The assumption of this perspective takes place at the expense of an in-depth micro understanding, from the perspective of which it is possible to notice other aspects of critical significance for the understanding of organizational paradoxes (Hargrave \& Van de Ven, 2017). This is where suggestions for further empirical studies, with the use of methods that would make it possible to immerse in the rich context of particular cases of $\mathrm{MNC}$, come from.

\section{REFERENCES}

1. Adler, P.S., Goldoftas, B., \& Levine, D.I. (1999). Flexibility versus Efficiency? A case study of model changeovers in the Toyota product system. Organization Science, 10, 43-68.

2. Andriopoulos, C., \& Lewis, M.W. (2009). Exploration-exploitation tensions and organizational ambidexterity: Managing paradoxes of innovation. Organization Science, 20, 696-717.

3. Argyris, C., \& Schön D. (1978). Organizational learning: A theory of action perspective. Reading, Mass: Addison Wesley.

4. Arthur, W. B. (2009). The Nature of Technology: What it is and How it Evolves. New York: Free Press.

5. Ashby, R. (1956). Introduction to cybernetics. London: Methuen,

6. Atuahene-Gima, K. (2005). Resolving the capability-rigidity paradox in new product innovation. Journal of Marketing, 69, 61-83.

7. Bartlett, C. A., \& Ghoshal, S. (1989). Managing across borders: The transnational solution. Boston: Harvard Business School Press.

8. Baum, J.A.C., Li, X.S., \& Usher, J.M. (2000). Making the next move: how experiential and vicarious learning shape the locations of chains' acquisitions. Administrative Science Quarterly, 45, 776-786. 
9. Benner, J.M., \& Thushman, M. (2002). Process management and technological innovation: A longitudinal study of the photography and paint industries. Administration Science Quarterly, 47, 679-706.

10. Benner, M.J., \& Tushman, M.L. (2003). Exploitation, exploration, and process management: The productivity dilemma revisited. Academy of Management Review, 28, 238-256.

11. Birkinshaw, J., \& Gibson, C.B. (2004). Building ambidexterity into organization. Sloan Management Review, (Summer), 47-55.

12. Burns, T., \& Stalker, G. (1961). The Management of Innovation. London: Tavistock.

13. Christensen, C. M., \& Bower, J.L. (1996). Customer power, strategic investment, and the failure of leading firms. Strategic Management Journal, 17, 197-218.

14. Christensen, C. M. (1997). The innovator's dilemma: when new technologies cause great firms to fail. Boston, Massachusetts: Harvard Business School Press.

15. Cyert, R., \& March, J.G. (1992). A behavioral theory of the firm (2 ed.). New York: Wiley-Blackwell.

16. Dooley, K., \& Van de Ven, A. (2017). 'Cycles of divergence and convergence: Underlying processes of organizational change and innovation'. In A. Langley, \& H. Tsoukas, (Eds.) The sage handbook of process organization studies. (pp. 593-600) Thousand Oaks. CA: Sage.

17. Dougherty, D. (1996). Organizing for Innovation. In S.R. Clegg, C. Hardy, \& W.R. Nord (Eds.) Handbook of organization studies. (pp. 424-439) Thousand Oaks: Sage.

18. Duncan, R. (1976). The ambidextrous organization: Designing dual structures for innovation. In: R.H. Killman, L.R. Pondy, \& D. Sleven (Eds.), The management of organization (pp. 167-188). New York: North Holland.

19. Dziubińska, A. (2015). Divergent and convergent approach to strategy process of MNCs - An evolutionary approach. International Journal of Arts \& Sciences, 08(01), 531-555.

20. Forsgren, M. (2008). Theories of multinational firm. a multidimensional creature in the global economy. Cheltenham, UK: Edward Elgar.

21. Gibson, C.B., \& Birkinshaw, J. (2004). The antecedents, consequences, and mediating role of organizational ambidexterity. Academy of Management Journal, 47, 209-226.

22. Giddiens, A. (1999). Runaway world. REITH LECTURES. Retrieved from http://downloads.bbc.co.uk/rmhttp/radio4/transcripts/1999_reith1.pdf

23. Greve, H.R. (2007). Exploration and exploitation in product innovation. Industrial and Corporate Change, 16, 945-975.

24. Gupta, A.K., Smith, K.G., \& Shalley, C. (2006). The interplay between exploration and exploitation. Academy of Management Journal, 49, 693-706. 
25. Hargrave, T. J., \& Van de Ven, A. H. (2017). Integrating dialectical and paradox perspectives on managing contradictions in organizations. Organization Studies, 38(3-4), 319-339.

26. He, Z-L., \& Wong P.-K. (2004). Exploration vs. exploitation: An empirical test of the ambidexterity hypothesis. Organization Science, 15, 481-494.

27. Hedberg, B. (1981). How Organizations learn and unlearn. In P.C. Nystrom, \& W. H. Starbuck (Eds.), Handbook of organizational design. (pp. 3-27). New York: Oxford University Press.

28. Huber, G. (1991). Organizational learning: The contributing processes and the literatures. Organization Science, 2, 88-115.

29. Hymer, S. (1960). The international operations of national firms: A study of foreign direct investment. Cambridge, Massachusetts: MIT Press.

30. Jansen, J. J., Simsek, Z., \& Cao, Q. (2012). Ambidexterity and performance in multiunit contexts: Cross-level moderating effects of structural and resource attributes. Strategic Management Journal, 33(11), 1286-1303.

31. Junni, P., Sarala, R. M., Taras, V., \& Tarba, S. Y. (2013). Organizational ambidexterity and performance: A meta-analysis. The Academy of Management Perspectives, 27(4), 299-312.

32. Kostova, T., \& Kendall, R. (2002). Adoption of an organizational practice by subsidiaries of multinational corporations: Institutional and relational effects. The Academy of Management Journal, 45, 215-233.

33. Levinthal, D.A., \& March G.J. (1993). The myopia of learning. Strategic Management Journal, 14, 95-112.

34. Lubatkin, M. H., Simsek, Z., Ling, Y., \& Veiga, J. F. (2006). Ambidexterity and performance in small-to medium-sized firms: The pivotal role of top management team behavioral integration. Journal of Management, 32(5), 646-672.

35. Luo, Y., \& Rui, H. (2009). An ambidexterity perspective toward multinational enterprises from emerging economies. Academy of Management Perspectives 23, 49-70.

36. Madhok, A., \& Liu, C. (2006). A coevolutionary theory of the multinational firm. Journal of International Management, 12, 1-12.

37. March, G. J. (1991). Exploration and exploitation in organisational learning. Organizational Science, 2, 71-87

38. McDonough, E. F., \& Leifer R. (1983). Using simultaneous structures to cope with uncertainty. Academy of Management Journal, 26. Retrieved from https://journals.aom.org/doi/abs/10.5465/255918

39. Mom, T. J., Van Den Bosch, F. A., \& Volberda, H. W. (2009). Understanding variation in managers' ambidexterity: Investigating direct and interaction effects of formal structural and personal coordination mechanisms. Organization Science, 20(4), 812-828. 
40. O’Reilly, C. A., \& Tushman, M. L. (2013). Organizational ambidexterity: Past, present, and future. The Academy of Management Perspectives, 27(4), 324-338.

41. Porter, M.E. (1996). What is Strategy? Harvard Business Review, 74, 61-81.

42. Porter, M.E. (1980). Competitive Strategy. New York: Free Press.

43. Probst, G. \& Büchel, B. (1997) .Organizational learning: The competitive advantage of the future. London: Prentice Hall.

44. Raisch S., Hargrave, T. J., Andrew, H. \& van de Ven (2018). The learning spiral: A process perspective on paradox. Journal of Management Studies. 55,(8), 1507-1526.

45. Raisch, S. (2008). 'Balanced structures: Designing organizations for profitable growth'. Long Range Planning, 41, 483-508.

46. Raisch, S., \& Birkinshaw, J. (2008). Organizational ambidexterity: Antecedents, outcomes, and moderators. Journal of Management, 34(3), 375-409.

47. Rokita, J. (2005). Zarzadzanie strategiczne. Tworzenie $i$ utrzymywanie przewagi konkurencyjnej. Warszawa: PWE.

48. Rosenkopf,L., \& Nerkar, A. (2001). Beyond local search: Boundaryspanning, exploration, and impact in the optical disc industry. Strategic Management Journal, 22, 287-306.

49. Schreyögg, G., \& Sydow, J. (2010). CROSSROADS-organizing for fluidity? Dilemmas of new organizational forms. Organization Science, 21(6), 12511262.

50. Sheremeta, A.W. (2000). Centrifugal and Centripetal forces in radical product development under time pressure. Academy Management Review, 25, 389-408.

51. Smith, W. K., \& Tushman, M. L. (2005). Managing strategic contradictions: A top management model for managing innovation streams. Organization Science, 16, 522-536.

52. Smith, W. K., \& Lewis, M. W. (2011). 'Toward a theory of paradox: A dynamic equilibrium model of organizing'. Academy of Management Review, 36, 381-403.

53. Smith, W. K., Lewis, M. W., \& Tushman, M. L. (2016). "Both/and” leadership. Harvard Business Review, 94(5), 1-8.

54. Thomas, C., Kaminska-Labbé, R. \& McKelvey, B. (2005). Managing the MNC and Exploitation/Exploration Dilemma: From Static Balance to Dynamic Oscillation. In G. Szulanski, J Porac, \& Y. Doz (Eds.) Strategy process. Advances in Strategic Management, Vol. 22, (pp. 213-247). Bingley: Emerald Group Publishing Limited.

55. Turner, N., Maylor, H., \& Swart, J. (2015). Ambidexterity in projects: An intellectual capital perspective. International Journal of Project Management, 33(1), 177-188. 
56. Tushman, M. L., \& Romanelli, E. (1985). Organizational evolution: A metamorphosis model of convergence and reorientation. Research in Organizational Behavior, 7, 171-223

57. Tushman, M.L., \& O’Reilly, Ch. A. (1996). The ambidexterous organization: Managing evolutionary and revolutionary change. California Management Review, 38, 1-23.

58. Tylor, A., \& Greve, H.P.(2006). Superman of fantastic four? Knowledge combination and experience in innovation teams. Academy of Management Journal, $49,723-740$.

59. Uotila, J. (2018). Punctuated equilibrium or ambidexterity: Dynamics of incremental and radical organizational change over time. Industrial and Corporate Change, 27, 131-48.

60. Vermeulen, G. A. M, \& Barkema, H.G. (2001). Learning through acquisitions. Academy of Management Journal, 44, 459.

61. Volberda, H. W. (2003). Strategic flexibility: Creating dynamic competitive advantages. In D.O. Faulkner, A. Campbell (Eds.) The Oxford Handbook of Strategy Volume II: Corporate Strategy (pp. 447-506) Oxford: Oxford University Press.

62. Volberda, H.W., \& Lewin A.Y. (2003). Co-evolutionary dynamics within and between firms: from evolution to co-evolution. Journal of Management Studies, 40, 2111-2136.

63. Weick, K. E. (1982). Management of organizational change among loosely coupled elements. In P. Goodman (Ed.). Change in organizations (pp. 375-408). San Francisco: Jossey-Bass.

64. Weick, K. E. (1979). The social psychology of organizations. (2nd ed) Reading, Mass: Addison-Wesley.

65. Zimmermann, A., Raisch, S., \& Birkinshaw, J. (2015). How is ambidexterity initiated? The emergent charter definition process. Organization Science, 26(4), 1119-1139. 